\title{
Comparative stomatal conductance and chlorophyll $a$ fluorescence in leaves vs. fruits of the cerrado legume tree, Dalbergia miscolobium
}

\author{
José Pires de Lemos Filho* and Rosy Mary dos Santos Isaias
}

Departamento de Botânica, Instituto de Ciências Biológicas, UFMG, CEP 31270-110, Belo Horizonte, MG, Brasil. *Corresponding author: lemos@icb.ufmg.br

Received: 16/03/2004, Accepted: 19/06/2004

The aim of this study was to compare water vapor conductance and chlorophyll $a$ fluorescence between leaflets and fruits of Dalbergia miscolobium, the Jacaranda tree. The frequency of stomata on the leaflets was 20 times higher than that observed on the fruits, and this was related with the lower conductance of the fruits in comparison with the leaflets. The potential quantum yield of PSII $\left(F_{v} / F_{\max }\right)$ was significantly lower in fruits than in leaflets. The $F_{v} / F_{\max }$ values for leaflets increased to over 0.8 during the afternoon, indicating the occurrence of dynamic photoinhibition. In contrast, $F_{v} / F_{\max }$ values for fruits remained low even at early morning, indicating the occurrence of chronic photoinhibition. The maximum values of effective quantum yield $\left(\Delta F / F_{i m}\right)$, and of the apparent electron transport rate (ETRmax) were higher in leaflets than in fruits. It was concluded that, like other green tissues, the pericarp of D. miscolobium was photosynthetically active, and therefore can contribute to the maintenance of the fruits and/or to the development of the seeds.

Key words: jacaranda tree, stomata, quantum efficiency of PSII, water vapor conductance.

Comparação da condutância estomática e da fluorescência da clorofila $a$ entre folhas e frutos de Dalbegia miscolobium, uma árvore do cerrado: $O$ objetivo deste estudo foi avaliar, comparativamente, a condutância ao vapor d'água e a eficiência fotoquímica, utilizando medidas de fluorescência da clorofila $a$, em folíolos e frutos de Dalbergia miscolobium, o jacarandádo-cerrado. A freqüência de estômatos nos folíolos foi 20 vezes superior à dos frutos, e este fato foi relacionado aos menores valores de condutância nos últimos, em comparação aos dos folíolos. O rendimento quântico potencial do PSII $\left(F_{v} / F_{\max }\right)$ foi significativamente inferior nos frutos quando comparados aos folíolos. Os valores de $F_{v} / F_{\max }$ para os folíolos aumentaram, durante a tarde, para acima de 0,8 , indicando fotoinibição dinâmica. Para os frutos, os valores de $F_{v} / F_{\max }$ permaneceram baixos, mesmo no início da manhã, revelando a fotoinibição crônica. As folhas apresentaram maior rendimento quântico efetivo $\left(\Delta F / F_{\text {'max }}\right)$ e maior taxa aparente de transporte de elétrons (ETR) do que os frutos. Pode-se concluir que o pericarpo dos frutos de D. miscolobium, como outros tecidos verdes apresentam alguma atividade fotossintética, podendo, portanto, contribuir para a manutenção dos frutos e/ou para o desenvolvimento das sementes.

Palavras-chave: jacarandá-do-cerrado, condutância ao vapor d'água, eficiência quântica do PSII, estômato.

\section{INTRODUCTION}

Reproductive plant organs impose a significant energy and carbon demand in relation to the total plant dry mass production (Bazzaz et al., 1979), since significant quantities of assimilates are translocated from leaves to flowers and developing fruits (Pavel and DeJong, 1993).
Several studies have reported that flowers, fruits, and pods of legumes have photosynthetic activity (Hansen, 1970; Crookston et al., 1974; Flinn et al., 1977), and so these reproductive structures should contribute with a fraction of the carbohydrates required for their development. These photosynthetic contributions from fruits are estimated in 
distinct ways, according to the species and type of structure, and they may vary from 5-9\% in peach (Pavel and DeJong, 1993 ) to $10 \%$ in cotton (Wullschlegn et al., 1991), and to $12 \%$ in pepper fruits (Steer and Pearson, 1976).

Even though the epidermis of fruits and pods may present less stomata than the epidermis of leaves, their function should be similar (Crookston et al., 1974; Atkins et al., 1977). This has been shown by the analysis of transpiration rates in immature fruits, whose epidermis constitute the main site of $\mathrm{CO}_{2}$ exchange, due to their lower diffusive resistance, as pointed out by Blanke and Lens (1989).

The majority of the studies on photosynthesis of fruits has been performed by the quantification of $\mathrm{CO}_{2}$ exchange (Goldstein et al., 1991; Pavel and DeJong, 1993; Blanke and Whiley, 1995; Marcelis and Hofman-Eijer, 1995), and, more recently, by chlorophyll fluorescence measurements (Hetherington et al. 1998; Smille et al., 1999). Most studies on photosynthesis in fruits have focused mainly on species of economic importance, while similar studies on wild species are relatively rare (Goldstein et al., 1991). Moreover, the available data on photosynthesis of Brazilian native species has focused on leaf behavior. Therefore, this study was carried out to compare photosynthesis in fruits and leaves of Dalbergia miscolobium (Jacaranda tree or jacaranda-ofcerrado), a legume tree native to Brazil, in an attempt to contribute to understand ecophysiological aspects related to the carbon economy of plants from Brazilian biomes.

\section{MATERIAL AND METHODS}

This study was performed in situ on three native trees of Dalbergia miscolobium Benth. (4-5 $\mathrm{m}$ height), growing in their natural habitat of the cerrado (Brazilian savanna) near Belo Horizonte ( $\left.19^{\circ} 51^{\circ} \mathrm{S}, 43^{\circ} 55^{\circ} \mathrm{W}\right)$, State of Minas Gerais, Brazil, at the end of the wet season (2001, March 27). Phenological observations indicated that leaf loss and fruit dispersal took place at the end of the dry season (end of August/beginning of September). Bud sprouting occurred just after leaf shedding, and flowering began after leaf maturation, during the rainy season, in February.

Stomata counting and measurements were done on excised epidermis of leaflets $(n=10)$ and fruits $(n=10)$ fixed, and stored in FAA (formalin: ethanol 50\%: acetic acid, 1:1:18, $\mathrm{v} / \mathrm{v})$. Epidermal fragments $\left(\sim 1 \mathrm{~cm}^{2}\right)$ were peeled off for $24 \mathrm{~h}$, at $60^{\circ} \mathrm{C}$, by Jeffrey's method stained with $1 \%$ safranin in $50 \%$ ethanol, and mounted in glycerin jelly (Johansen, 1940). Photographs were taken using an Olympus SZH photomicroscope. Stomata density were measured using an
Olympus BH2-DA drawing attachment connected to an Olympus light microscope, and measurements of stomata pore area $(\mathrm{n}=50)$ were made using an image analysis software (Motic Images 2000- Canada).

Physiological parameters were measured at the end of March, when fruits reached maximum size, but seeds were still immature. Leaf and fruit conductance were determined with a diffusion porometer AP4 (Delta-T, UK), and chlorophyll $a$ fluorescence measurements made with a portable chlorophyll fluorometer MINI-PAM (Walz, Germany). Maximum $\left(F_{\text {max }}\right)$ and basal $\left(F_{o}\right)$ fluorescence yield were measured in dark-adapted (30 min) leaflets or fruits for determination of the potential quantum yield of photosystem II - PSII $\left(F_{v} / F_{\max }=F_{\max }-F_{o} / F_{\max }\right)$. The effective quantum yield of the PSII $\left(\Delta F / F_{i_{m}}\right)$ was calculated as $\left(F_{r_{\text {max }}}-F\right) / F_{r_{\text {max }}}$ where $\mathrm{F}$ is the steady-state fluorescence in the light, and $F_{\text {'max }}$ is the maximum fluorescence in the light when a saturating light was imposed. The apparent electron transport rate (ETR) was obtained according to Lüttge et al. (1998), ETR $=0.5(\Delta F /$ $\left.F_{\text {max }}\right) . P P F$, where 0.5 is a factor that takes into account the light excitation of the two photosystems, $\Delta F / F_{\text {max }}$ is the effective quantum yield of PSII, and $P P F$ the photosynthetic photon flux density determined with a quantum sensor (LI-COR) at the exposition plane, considering that both leaflets and fruits of D. miscolobium have vertical orientations. These precautions in relation to light measurements were taken due to the effects of the leaflet orientation on the rate of photochemical reactions as observed in Pterodon pubescens by Caldas et al. (1997). All measurements were made on two leaflets and two fruits per plant.

\section{RESULTS AND DISCUSSION}

The adaxial epidermis of leaflets was composed of polygonal 4-5 side cells, of-irregular shapes, and randomly orientated. Trichome basal cells were noted by the radially disposed basic epidermal cells around them. The abaxial epidermis of leaflets was composed of polygonal cells, with size and shape similar to those of the adaxial epidermis. Stomata were predominantly paracytic, but anomocytic ones were also observed. Guard and subsidiary anticlinal cell walls were thinner than those of the basic epidermal cells (figure 1A). Trichome basal cells were similar to those of the adaxial side of the blade. Fruit epidermis was composed of polygonal 4-5 side cells, with irregular shapes, randomly orientated, and larger than those of the leaflets. Trichomes were not observed. Stomata were exclusively anomocytic, and were larger than those of the leaflets (figure 1B). 


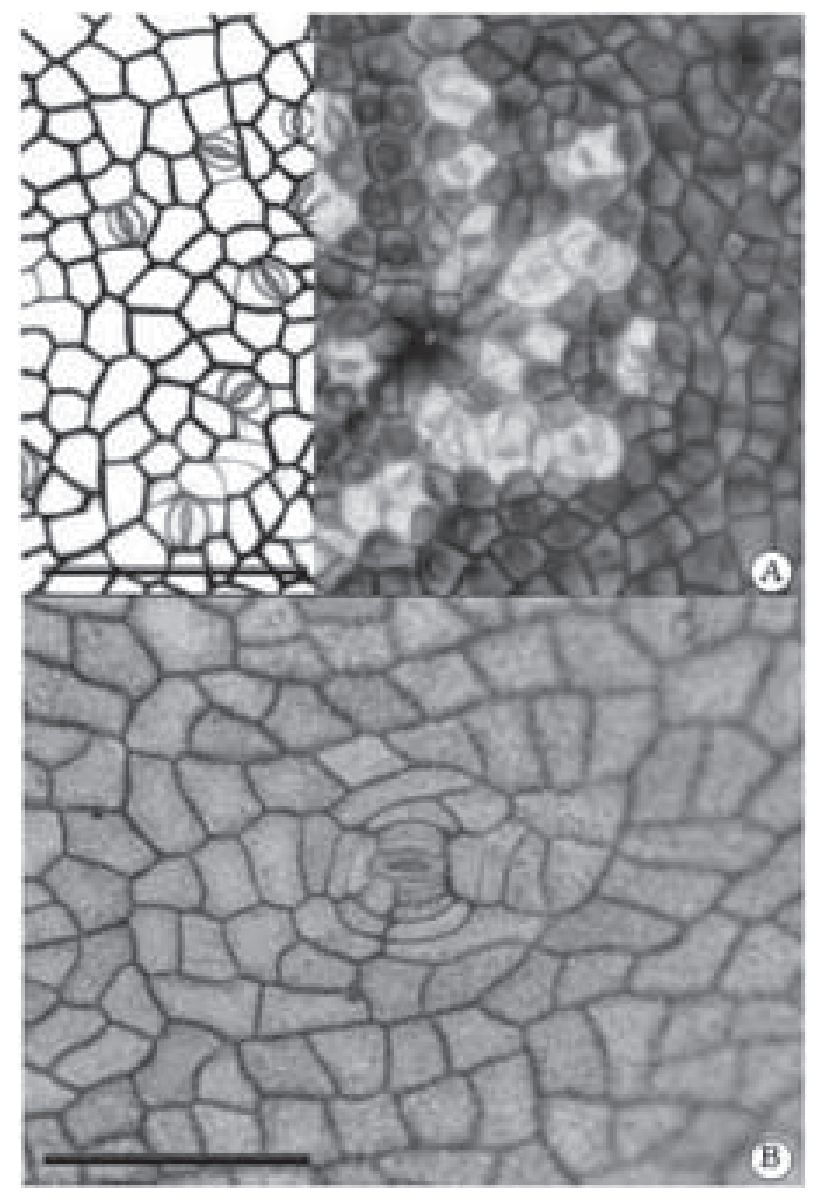

Figure 1. Abaxial epidermis of leaflets (A) and epidermis of fruits (B) of D. miscolobium (bars $=100 \mu \mathrm{m}$ ).

According to Mauseth (1988), during fruit development no new stomata are usually initiated, so their density decreases as the fruit becomes larger, and this was particularly true for D. miscolobium mature fruits. In addition, it was observed that both basic epidermal and guard cells were larger in fruits than leaflets, suggesting that cell enlargement was more important than cell division or differentiation during fruit maturation.

Stomata frequency on the epidermis of D. miscolobium fruits was approximately 20 -fold lower than for the abaxial epidermis of the leaflets (table 1). This order of magnitude agrees with Blanke and Lenz (1989), who pointed out that stomata on the outer epidermis of a fruit might be 10 to 100 fold less frequent than in the leaf abaxial epidermis of the same species. In the current study, stomata frequency on the fruit epidermis was approximately $4.6 \%$ of that on the leaflet abaxial epidermis, and significantly less frequent than the values of broad bean or pea pod epidermis, which were $27 \%$ and $25 \%$ as frequent as on the leaflet surface (Willmer and Johnston, 1976; Atkins et al., 1977).
Table 1. Stomata pore area (Ast), stomata frequency (nst) and fraction of the surface area occupied by stomata pores (Ast/A) on abaxial epidermis of leaflets and on epidermis of D. miscolobium pods (mean $\pm \mathrm{SD}, \mathrm{n}=10$ ).

\begin{tabular}{ccc}
\hline & Leaflets & Pods \\
\hline Ast $\left(\mu \mathrm{m}^{2}\right)$ & $84.1 \pm 27.7$ & $166.2 \pm 63.7$ \\
nst $\left(\mathrm{st} . \mathrm{mm}^{-2}\right)$ & $72.11 \pm 31.11$ & $3.31 \pm 1.6$ \\
Ast/A $(\%)$ & $0.61 \pm 0.39$ & $0.056 \pm 0.037$ \\
\hline
\end{tabular}

The stomata pore area of fruits of D. miscolobium was larger than that of leaflets, but due to lower stomatal frequency, the fraction of fruit epidermis surface area occupied by stomata pores (Ast/A) corresponds to just $9 \%$ of the Ast/A of the leaflet abaxial epidermis (table 1). The difference in Ast/ A between fruits and leaflets resulted in the lowest conductance values being observed on fruits. In the morning measurements, fruit conductance, $29 \pm 4 \mathrm{mmol} \cdot \mathrm{m}^{-2} \cdot \mathrm{s}^{-1}$, corresponded to $7.8 \%$ of that of leaflets, $378 \pm 165 \mathrm{mmol} \cdot \mathrm{m}^{-2} \cdot \mathrm{s}^{-1}$ (figure $2 \mathrm{~A}$ ), which were similar to the leaf conductance of three other cerrado woody species in the wet season (Lemos Filho, 2001). In the fruits, the lowest values of stomatal conductance were constant during the day. The patterns of D. miscolobium leaflets were similar to those observed for Qualea grandiflora, another cerrado tree (Franco and Lüttge, 2002). The maximum conductance values occurred early in the morning, followed by a continuous decrease at noon, with a small recovery around 2:00 pm, and an expressive decrease in the afternoon, with the lowest incident light values (figure 2B).

Similar to the pattern observed for the water vapor exchange, the potential quantum yield of PSII $\left(F_{v} / F_{\text {max }}\right)$ at 10:00 $\mathrm{h}$ was lower in fruits $(0.447 \pm 0.07)$ when compared to that of leaflets $(0.768 \pm 0.04)$ (figure $3 \mathrm{~A})$. As a consequence of the decrease of the incident light levels in the afternoon, the $F_{v} / F_{\max }$ values of fruits rose, but they were always inferior to those observed in leaflets.

When exposed to excessive light, PSII function can be affected by photoinhibition (Barber and Anderson, 1992). Considering 0.8 as a threshold $F_{v} / F_{\max }$ value for photoinhibition, as suggested by Lütge et al. (1998), the measurements in both leaflets and fruits indicated excessive incident light level noon. The midday $F_{v} / F_{\max }$ values of leaflets increased up to values higher than 0.8 with the decreasing light irradiance in the afternoon, which characterizes the occurrence of dynamic photoinhibition (Osmond, 1994). In this case, the excess of photon flux should have been dissipated by non-photochemical pathways in a 
protective down-regulation of PSII mediated by the xanthophylls cycle (Demmig-Adams and Adams, 1996). However, in fruits of D. miscolobium, the $F_{v} / F_{\text {max }}$ values were constantly below the threshold value, even in the early morning, indicating a chronic photoinhibition, similarly to that observed by Mattos et al. (2002) in leaves of Miconia albicans, a cerrado shrub. The chronic photoinhibition involves photon damage to the functional integrity of the PSII reaction center when the proteolysis of the $\mathrm{D} 1$ protein of the reaction center core exceeds the rate of repair (Osmond, 1994).

The effective quantum yield of the PSII $\left(\Delta F / F_{\text {'max }}\right)$ for both leaflets and fruits dropped with the increase of incident light in the morning (figure 3B). Leaflet $\Delta F / F_{\text {max }}$ values were also higher than those of fruits with the highest difference in the afternoon, in spite of the decrease of incident light. The
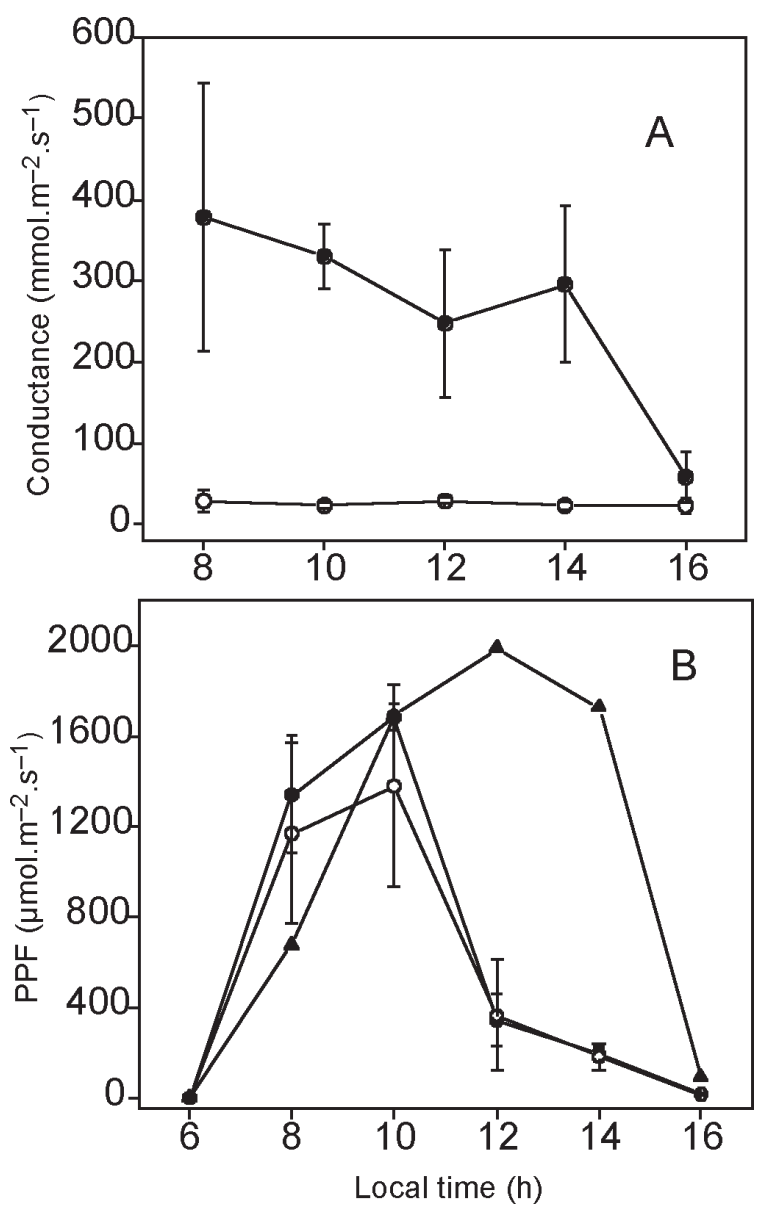

Figure 2. Diurnal changes of the water vapor conductance of abaxial epidermis of leaflets (closed symbols) and pods (open symbols) (A) and diurnal changes on the photosynthetic photon flux $(P P F)$ at horizontal plane (triangle) and incident on the plane of leaflets (closed circle) and on pods (open circle) (B) of D. miscolobium (March, 27, 2001). Data expressed as mean \pm SD, $n=6$ fruits or leaflets. maximum apparent ETR values for leaflets were also higher than those observed in fruits; $335 \pm 97 \mu$ mol. $\mathrm{m}^{-2} \cdot \mathrm{s}^{-1}$ and 151 $\pm 49 \mu \mathrm{mol} . \mathrm{m}^{-2} \cdot \mathrm{s}^{-1}$, respectively (figure $3 \mathrm{C}$ ). These highest ETR values were not only a result of the highest incident light on leaflets (figure3), but they were mainly due to the effective quantum yield of PSII $\left(\Delta F / F_{\text {max }}\right)$ being higher in leaflets than in fruits. Using chlorophyll fluorescence techniques to access the photosynthetic activity of vegetative and fruiting tissues of tomato fruits, Hetherington et al. (1998) found that the maximum ETR varied from 110 to $330 \mu \mathrm{mol} . \mathrm{m}^{-}$ ${ }^{2} \cdot \mathrm{s}^{-1}$, with the highest values measured in leaf lamina and the lowest ones for fruit, a result similar to that obtained in the present study.

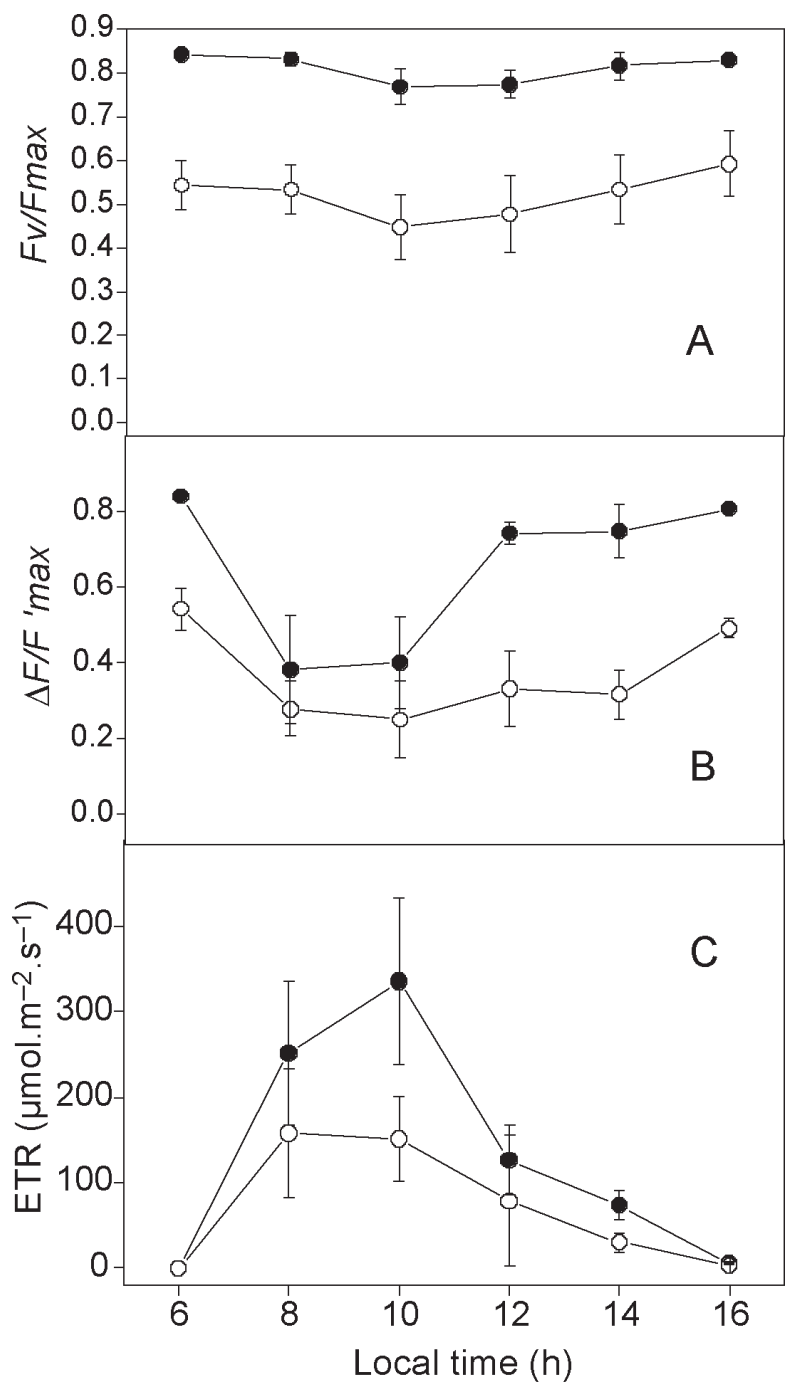

Figure 3. Diurnal changes on photosynthetic-related parameters of leaflets (closed symbols) and fruits (open symbols) of D. miscolobium: potential quantum yield of the PSII $\left(F_{v} / F_{\max }\right)(\mathrm{A})$, effective quantum yield of PSII $\left(\Delta F / F_{\text {max }}\right)(\mathrm{B})$, and apparent electron transport rate (ETR) (C). Data expressed as mean $\pm \mathrm{SD}, \mathrm{n}=6$ fruits or leaflets. 
The $\mathrm{CO}_{2}$ evolution rates of illuminated fruits were lower than those of fruits in darkness, indicating that they fix $\mathrm{CO}_{2}$, but the dark respiration was not fully compensated by light fixation in most fruit pods (Pavel and De Jong, 1993). However, according to Goldstein et al. (1991), the photosynthetic activity of the pod pericarp helped support not only the cost of fruit maintenance, but also the cost of its growth, particularly during the first stages of development, considering that, during late fruiting stages, insufficient carbon is fixed to fully support either respiration or growth. Even though the photosynthetic performance of D. miscolobium fruits was lower than that of leaflets, the photosynthetic activity found for the pericarp, as shown for many green tissues other than leaf mesophyll, was likely to be relevant in the provision of carbon assimilates, and thus should contribute to fruit maintenance and/or seed development.

In addition, it is of interest to consider the ETR results obtained using the chlorophyll fluorescence technique in terms of oxygen evolution, since four electrons are generated per molecule of oxygen released, as a result of water splitting. Considering that fruits could maintain a high internal $\mathrm{CO}_{2}$ concentration, as shown for tomato fruits (Czarnowski and Starzecki, 1992), the oxygen evolution by the pericarp could be important to avoid or reduce internal anaerobiosis, as suggested by Pfanz et al. (2002) for green tree stems.

Acknowledgments: We thank the Fundação de Amparo à Pesquisa do Estado de Minas Gerais (FAPEMIG) for financial support of this study, and G. Uemura for reviewing the text. J.P.LF is grateful to CNPq for the awarded fellowship.

\section{REFERENCES}

Atkins CA, Kuo J, Pate JS, Flinn AM, Steele TW (1977) Photosynthetic pod wall of pea (Pisum sativum L). Plant Physiol. 60:779-786.

Barber J, Anderson B (1992) Too much of a good thing: light can be bad for photosynthesis. Trends Bioch. Sci. 17:61-66.

Bazzaz FA, Carlson RW, Harper JL (1979) Contribution to reproductive effort by photosynthesis of flowers and fruits. Nature 279:554-555.

Blanke MM, Lenz F (1989) Fruit photosynthesis. Plant Cell Environ. 12:31-46.

Blanke MM, Whiley AW (1995) Bioenergetics, respiration cost, and water relations of developing avocado fruit. J. Plant Physiol. 145:87-92.

Caldas LA, Lüttge U, Franco AC, Haridasan M (1997) Leaf heliotropism in Pterodon pubescens, a wood legume from Brazilian cerrado. Rev. Bras. Fisiol. Veg. 9:1-7.

Demmig-Adams B, Adams WW (1996) The role of xanthophylls cycle carotenoids in protection of photosynthesis. Trends Plant Sci. 1:21-26.

Crookston RK, O‘Toole J, Ozbun JL (1974) Characterization of the bean pod as a photosynthetic organ. Crop Sci. 14:708-712.
Czarnowski M, Starzecki W (1992) Spectral properties and $\mathrm{CO}_{2}$ exchange of tomato fruits. Photosynthetica 27:513-519.

Flinn AM, Atkins CS, Pate JS (1977) Significance of photosynthetic and respiratory exchanges in the carbon economy of developing pea fruit. Plant Physiol. 60:412-418.

Franco AC, Lüttge U (2002) Midday depression in savanna trees: coordinated adjstements in photochemical efficiency, photorespiration, $\mathrm{CO}_{2}$ assimilation and water use efficiency. Oecologia 131:356-365.

Goldstein G, Sharifi MR, Kohorn LU, Lighton JRB, Shultz L, Rundel PW (1991) Photosynthesis by inflated pods of a desert srub, Isomeris arborea. Oecologia 85:396-402.

Hansen P $(1970){ }^{14} \mathrm{C}$-studies on apple trees. VI. The influence of the fruit on the photosynthesis of the leaves, and the relative photosynthetic yields of fruits and leaves. Physiol. Plant. 25:469-473.

Hetherington SE, Smillie RM, Davies WJ (1998) Photosynthetic activities of vegetative and fruiting tissues of tomato. J. Exp. Bot. 49:1173-1181.

Johansen (1940) Plant microtechnique. MacGraw Hill Book Co. New York.

Lemos Filho JP (2000) Fotoinibição em três espécies do cerrado (Annona crassifolia, Eugenia dysenterica e Campomanesia adamantium) na estação seca e na chuvosa. Rev. Bras. Bot. 23:45-50.

Lüttge U, Haridasan M, Fernandes GW, Mattos EA, Trimborn P, Franco AC, Caldas LS, Ziegler H. (1998) Photosynthesis of mistletoes in relation to their hosts at various sites in tropical Brazil. Trees-Struct. Funct.12:167-174.

Marcelis LFM, Hofman-Eijer LRB (1995) Growth and maintenance respiratory costs of cucumber fruits as affected by temperature, and ontogeny and size of the fruits. Physiol. Plant. 93:489-492.

Mattos EA, Lobo PC, Joly CA (2002) Overnight rainfall inducing rapid changes in photosynthetic behaviour in a cerrado wood species during a dry spell amidst the rainy season. Aust. J. Bot. 50:241-246.

Mauseth J (1988) Plant anatomy. The Benjamin Cummings Pub. Co. Menlo Park.

Osmond CB (1994). What is photoinhibition? Some insights from comparison of shade and sun plants. In: Baker RR, Bowyer JR (eds.) Photoinhibition of photosynthesis, pp 1-24. . Bios Scientific Publishers Ltda. Oxford

Pavel EW, De Jong TM (1993) Seasonal $\mathrm{CO}_{2}$ exchange patterns of developing peach (Prunus persica) fruits in response to temperature, light and $\mathrm{CO}_{2}$ concentration. Physiol. Plant. 88:322-330.

Pfanz H, Aschan G, Langenfeld-Heyser R (2002) Ecology and ecophysiology of tree stems: corticular and wood photosynthesis. Naturwissenschaften 89:147-162.

Smille RM, Hetherington, SE, Davies WJ (1999) Photosynthetic activity of the calyx, green shoulder, pericarp, and locular parenchyma of tomato fruit. J. Exp. Bot. 50:707-718.

Steer BT, Pearson CJ (1976) Photosynthate translocation in Capsicum annuum. Planta 128:155-162.

Willmer CM, Johnston WR (1976) Carbon dioxide assimilation in some aerial plant organs and tissues. Planta 130:33-37.

Wullschlegn SD, Oosterhuis DM, Hurren RG, Hanson PJ (1991) Evidence for light-dependent recycling of respired carbon dioxide by cotton fruit. Plant Physiol. 97:574-579. 